\title{
Congenital Cyanogenic Heart Disease in Children: About 420 Cases in Africa
}

\author{
Amadou Lamine Fall1', Amadou Sow ${ }^{2 *}$, Idrissa Basse ${ }^{3}$, Aliou Mar Coundoul1, \\ Fondjo P. S. Monoue1, Aliou Thiongane', Djibril Boiro', Indou Deme Ly¹, Babacar Niang1, \\ Idrissa Demba Ba1', Guilaye Diagne1, Papa Moctar Faye1, Ousmane Ndiaye1
}

\author{
${ }^{1}$ Albert Royer National Children's Hospital, Dakar, Senegal \\ ${ }^{2}$ Abass Ndao Hospital Center, Dakar, Senegal \\ ${ }^{3}$ Diamniadio Children's Hospital, Dakar, Senegal \\ Email: ^amadousoow@hotmail.com
}

How to cite this paper: Fall, A.L., Sow, A., Basse, I., Coundoul, A.M., Monoue, F.P.S., Thiongane, A., Boiro, D., Ly, I.D., Niang, B., Ba, I.D., Diagne, G., Faye, P.M. and Ndiaye, O. (2020) Congenital Cyanogenic Heart Disease in Children: About 420 Cases in Africa. World Journal of Cardiovascular Surgery, $10,83-90$

https://doi.org/10.4236/wjcs.2020.106011

Received: May 15, 2020

Accepted: June 20, 2020

Published: June 23, 2020

Copyright $\odot 2020$ by author(s) and Scientific Research Publishing Inc. This work is licensed under the Creative Commons Attribution International License (CC BY 4.0).

http://creativecommons.org/licenses/by/4.0/ (c) (i) Open Access

\begin{abstract}
Congenital cyanogenic heart disease (CCHD) is a malformation of the heart and large vessels characterized by an oxygen desaturation in the arterial blood, responsible for cyanosis. The general objective was to study the profile of CCHD in Senegalese hospitals. This is a retrospective study carried out over a period of 8 years (January 1, 2010 - December 31, 2017) and including all children aged 0 to 16 years followed for a CCHD. The hospital prevalence was $0.87 \%$ for 420 cases collected. The sex ratio was 1.44 and the average age at diagnosis was 16 months. First degree parental consanguinity was noted in 36 cases $(30.78 \%)$. The main reasons for consultation were breathing difficulty in 242 cases (57.62\%) and fever in 136 patients (32.36\%). Apart from cyanosis, the clinical signs were dominated by the heart murmur in 313 cases (74.7\%), tachycardia in 283 cases $(67.38 \%)$ and digital hippocratism in 162 cases (38.57\%). Cardiomegaly was found in 239 patients (83.36\%). The main types of CCHD were tetralogy of Fallot and transposition of the large vessels. In biology, 206 patients (49.05\%) presented polyglobulia. A complete surgical cure was carried out in 22 patients (5.24\%). Complications were anoxic crisis (52 cases) and hemorrhagic syndrome (17 cases). There were 97 deaths (28.28\%) during hospitalization. The diagnosis of CCHD is late in our country and surgical management is poor explaining the high mortality.
\end{abstract}

\section{Keywords}

Heart Disease, Cyanosis, Tetralogy Fallot, Surgery, Senegal 


\section{Introduction}

Congenital cyanogenic heart diseases (CCHD) are malformations of the heart and large vessels characterized by an oxygen desaturation in the arterial blood, responsible for a blue coloration of the mucous membranes and the integuments or cyanosis [1]. Congenital heart diseases (CHD) in general represent the most frequent congenital malformations, in particular $40 \%$ of all fetal malformations [2]. The diagnosis of CHD in general has known advances linked to the development of cardiovascular imaging, dominated by echocardiography coupled with color doppler [3]. Today, prenatal diagnosis is possible linked to progress in fetal cardiology through two-dimensional or even three-dimensional fetal echocardiography. This prenatal diagnosis made it possible to reduce the mortality of certain heart diseases by promoting optimal conditions for neonatal care [4] [5].

According to a last study in Senegal, CCHD represents $36.95 \%$ of all congenital heart diseases (CHC). Despite considerable advances in diagnosis with the contribution of cardiac ultrasound coupled with color doppler as well as progress in management with the development of pediatric cardiology and cardiovascular surgery, CCHD remains a major public health problem [6]. Studies have been carried out in our country on CHC in general but not specifically on CCHD [7] [8]. Thus, we carried out this work to study the profile of CCHD in Senegalese hospitals.

\section{Methodology}

This is a retrospective and descriptive study carried out at the Albert Royer National Children's Hospital (ARNCH) which is a benchmark public hospital for pediatric care in Senegal. It houses a pediatric cardiology department where the majority of children suffering from congenital or acquired heart disease are followed. The study was carried out over an 8-year period from January 1, 2010 to December 31, 2017 and including all children aged 0 to 16 years followed for CCHD confirmed on echocardiography by a pediatric cardiologist. The epidemiological, diagnostic, therapeutic and evolutionary parameters were informed from medical records and hospital registers. The data were entered with the Epi Info version 7 software. The qualitative variables were assessed by determining the numbers, the percentages and highlighting the mode. We did not have an ethical problem.

\section{Results}

During the study, 420 patients were collected for CCHD including 343 (81.67\%) in hospital with a prevalence of $0.87 \%$ (343/39336). The sex ratio was 1.44 and the average age at diagnosis was 16 months [extreme 0 day - 126 months]. No antenatal diagnosis has been made. First degree parental consanguinity was noted in 36 patients (30.78\%) and second degree consanguinity in 56 patients (47.86\%). The age of the mothers was between 20 and 29 years for 116 patients (49.36\%). Family socioeconomic level was low for 130 patients (60.19\%). Among 
the patients, 135 (77.59\%) were of low birth weight. The socio-demographic characteristics are summarized in Table 1 . The main reasons for consultations were breathing difficulty for 242 patients (57.62\%), fever for 136 patients (32.36\%) and cough for 92 patients (21.9\%). The main clinical signs are summarized in Table 2. Bronchiolitis was associated with CCHD in 84 patients $(55.63 \%)$ and trisomy 21 in 15 patients (3.3\%). Radiological cardiomegaly was found in 239 patients $(83.36 \%)$. The main types of CCHD found on cardiac ultrasound are illustrated in Table 3. In biology, 206 patients (49.05\%) presented polyglobulia, 153 patients $(36.4 \%)$ had anemia and 135 patients $(32,14 \%)$ hyponatremia. Therapeutically, 214 patients (58.63\%) were on loop diuretics, 204 patients $(55.89 \%)$ on beta-blockers, 35 patients (9.59\%) on digitalis and 67 patients (18.36\%) on converting enzyme inhibitors. A complete surgical cure was performed in $22 \mathrm{pa}-$ tients (5.24\%) including 15 cases of Tetralogy of Fallot (T4F). The average age at surgery was 52 months [ 4 months - 132 months]. Among the patients, 9 had undergone a Blalock and 10 others had an interventional catheterization of Rashkind. The evolution in hospitalization was favorable in 246/343 hospitalized or $71.72 \%$. Complications were dominated by anoxic discomfort (52 cases) and hemorrhagic syndrome (17 cases). We deplored 97 deaths (28.28\%) during hospitalization. Out of 420 patients, 202 were followed up remotely with 17 deaths (8.42\%) at an average age of 18 months [range 3 months and 60 months]. For T4F patients, the sex ratio was 1.66 , the average age at diagnosis was 25 months, and the fatality rate was $14.20 \%$. While for patients followed for transposition of large vessels (TLV), the sex ratio was 1.42 , the average age at diagnosis was around 4 months and the lethality was $32.76 \%$. The epidemiological, paraclinical and evolutionary features of the main types of CCHD are reported in Table 4 and Table 5.

Table 1. Socio-demographic characteristics.

\begin{tabular}{ccc}
\hline Parameters & & Percentage \\
\hline \multirow{2}{*}{ Sex } & Boys & 59.05 \\
& Girls & 41.95 \\
& Newborn & 8.88 \\
& Infant & 63.68 \\
Age & Early childhood & 8.58 \\
& Middle childhood & 9.47 \\
& Great childhood & 5.92 \\
& Teenager & 1.48 \\
& Low & 60.19 \\
& Medium & 38.43 \\
\hline
\end{tabular}


Table 2. The clinical manifestations of cyanogenic congenital heart disease.

\begin{tabular}{|c|c|c|c|}
\hline \multicolumn{2}{|c|}{ Clinical signs } & Workforce & Percentages (\%) \\
\hline \multicolumn{2}{|c|}{ Breath } & 313 & 74.72 \\
\hline \multicolumn{2}{|c|}{ Tachycardia } & 283 & 67.38 \\
\hline \multirow{4}{*}{ Cyanosis } & Peripheral & 63 & 23.86 \\
\hline & Central & 36 & 13.64 \\
\hline & Peripheral and central & 109 & 41.29 \\
\hline & Not tagged & 56 & 21.21 \\
\hline \multicolumn{2}{|c|}{ Respiratory distress } & 250 & 59.52 \\
\hline \multicolumn{2}{|c|}{ Digital Hippocratism } & 162 & 38.57 \\
\hline \multicolumn{2}{|c|}{ General condition deterioration } & 149 & 35.48 \\
\hline \multicolumn{2}{|c|}{ Heart failure } & 149 & 35.48 \\
\hline \multicolumn{2}{|c|}{ Desaturation } & 107 & 25.48 \\
\hline \multirow{2}{*}{ Statural delay } & Light to moderate & 43 & 53.75 \\
\hline & Severe & 37 & 46.25 \\
\hline \multirow{2}{*}{ Weight delay } & Light to moderate & 1 & 10.00 \\
\hline & Severe & 9 & 90.00 \\
\hline \multirow{3}{*}{$\begin{array}{l}\text { Weight-statural } \\
\text { delay }\end{array}$} & Light to moderate & 3 & 21.43 \\
\hline & Severe & 6 & 42.86 \\
\hline & Not tagged & 5 & 35.71 \\
\hline \multirow{3}{*}{ Undernutrition } & Mild to moderate & 14 & 29.17 \\
\hline & Severe & 23 & 47.92 \\
\hline & Not tagged & 11 & 22.91 \\
\hline \multicolumn{2}{|c|}{ Psychomotor delay } & 83 & 19.76 \\
\hline \multicolumn{2}{|c|}{ State of shock } & 26 & 6.19 \\
\hline \multicolumn{2}{|c|}{ Convulsion } & 8 & 1.90 \\
\hline
\end{tabular}

Table 3. Main types of cyanogenic congenital heart disease found on cardiac ultrasound.

\begin{tabular}{ccc}
\hline Types of congenital cyanogenic heart disease & Workforce & Percentages (\%) \\
\hline Tetralogy of Fallot & 162 & 38.57 \\
Transposition of Big Vessels & 58 & 13.81 \\
Double Issue Right Ventricle & 57 & 13.57 \\
Tricuspid Atresia & 38 & 9.06 \\
Common Arterial Trunk & 27 & 6.43 \\
Single Ventricle & 18 & 4.29 \\
Open Septum Pulmonary Atresia & 16 & 3.81 \\
Complex Cyanogenic Congenital Heart Disease & 14 & 3.33 \\
Total Abnormal Pulmonary Venous Return & 13 & 3.09 \\
Single Headset & 9 & 2.14 \\
Ebstein's disease & 4 & 0.95 \\
Intact Septum Pulmonary Atresia & 3 & 0.71 \\
Left Ventricle Double Issue + SP + D-MGV & 1 & 0.24 \\
Total & 420 & 100.00 \\
\hline
\end{tabular}


Table 4. Epidemiological, paraclinical and evolutionary features of the main CCHD.

\begin{tabular}{|c|c|c|c|c|c|c|c|c|}
\hline \multirow{2}{*}{$\begin{array}{l}\text { Types of } \\
\text { CCHD }\end{array}$} & \multicolumn{3}{|c|}{ Epidemiological data } & \multicolumn{4}{|l|}{ Paraclinical data } & \multirow[t]{2}{*}{ Death } \\
\hline & $\begin{array}{l}\text { Sex } \\
\text { ratio }\end{array}$ & $\begin{array}{l}\text { Parental } \\
\text { consanguinity }\end{array}$ & $\begin{array}{l}\text { Average age } \\
\text { of diagnosis }\end{array}$ & Chest x-ray & ECG & Heart ultrasound & Blood count & \\
\hline $\mathrm{T} 4 \mathrm{~F}$ & 1.66 & $47.50 \%$ & 25 months & $\begin{array}{l}\text { Cardiomegaly }(78.79 \%) \\
\text { Hypovascularization } \\
(41.41 \%)\end{array}$ & $\begin{array}{l}\text {-Right axis } \\
(60.38 \%) \\
- \text { RVH }(81.13 \%)\end{array}$ & $\begin{array}{l}\text {-SEF alteration } \\
(0.62 \%) \\
\text {-Endocarditis }(1.85 \%)\end{array}$ & $\begin{array}{l}\text {-Anemia }(31.48 \%) \\
\text {-Polyglobulia } \\
(63.58 \%)\end{array}$ & $14.20 \%$ \\
\hline TLV & 1.42 & $25.71 \%$ & 4 months & $\begin{array}{l}\text { Cardiomegaly }(94.29 \%) \\
\text { Hypovascularization } \\
(17.14 \%)\end{array}$ & $\begin{array}{l}\text {-Right axis (50\%) } \\
\text {-HVD }(66.66 \%)\end{array}$ & -PAH (18.96\%) & $\begin{array}{l}\text {-Anemia }(31.03 \%) \\
\text {-Polyglobulia } \\
(36.21 \%)\end{array}$ & $32.76 \%$ \\
\hline DIRV & 2.35 & $30.77 \%$ & 11 months & $\begin{array}{l}\text { Cardiomegaly }(91.30 \%) \\
\text { Hypervascularization } \\
(26.09 \%)\end{array}$ & $\begin{array}{l}\text {-Right axis (60\%) } \\
\text {-LVH (60\%) }\end{array}$ & $\begin{array}{l}\text {-PAH }(31.58 \%) \\
\text {-SEF alteration } \\
(1.75 \%) \\
\text {-Endocarditis }(3.51 \%)\end{array}$ & $\begin{array}{l}\text {-Anemia }(57.89 \%) \\
\text {-Polyglobulia } \\
(31.58 \%)\end{array}$ & $28.07 \%$ \\
\hline TA & 0.81 & $60 \%$ & 5 months & $\begin{array}{l}\text { Cardiomegaly }(88.46 \%) \\
\text { Hypovascularization } \\
(30.77 \%)\end{array}$ & $\begin{array}{l}\text {-Axis to the left } \\
(60 \%) \\
\text {-RVH }(40 \%)\end{array}$ & -PAH (18.42\%) & $\begin{array}{l}\text {-Anemia }(23.68 \%) \\
\text {-Polyglobulia }(50 \%)\end{array}$ & $44.74 \%$ \\
\hline
\end{tabular}

$\mathrm{CCHD}=$ congenital cyanogenic heart disease, $\mathrm{ECG}=$ electrocardiogram, $\mathrm{T} 4 \mathrm{~F}=$ Tetralogy of fallot, $\mathrm{TLV}=$ transposition of the large vessels, $\mathrm{DIRV}=$ double issu right ventricle, $\mathrm{TA}=$ tricuspid atresia, $\mathrm{RVH}$ = right ventricle hypertrophy, $\mathrm{LVH}=$ left ventricle hypertrophy, $\mathrm{PAH}=$ pulmonary arterial hypertension, $\mathrm{SEF}=$ systolic ejection fraction.

Table 5. Epidemiological, paraclinical and evolutionary features of the main CCHD.

\begin{tabular}{|c|c|c|c|c|c|c|c|c|}
\hline \multirow{2}{*}{$\begin{array}{l}\text { Types of } \\
\text { CCHD }\end{array}$} & \multicolumn{3}{|c|}{ Epidemiological data } & \multicolumn{4}{|l|}{ Paraclinical data } & \multirow[t]{2}{*}{ Death } \\
\hline & Sex ratio & $\begin{array}{l}\text { Parental } \\
\text { consanguinity }\end{array}$ & $\begin{array}{l}\text { Average age } \\
\text { of diagnosis }\end{array}$ & Chest x-ray & ECG & Heart ultrasound & Blood count & \\
\hline CAT & 1.08 & $41.18 \%$ & 9 months & $\begin{array}{l}\text {-Cardiomegaly } \\
(80.95 \%) \\
\text {-Hypovascularization } \\
(14.29 \%)\end{array}$ & $\begin{array}{l}\text { RVH and LVH } \\
(50 \%)\end{array}$ & $\begin{array}{l}\text {-PAH }(14.81 \%) \\
\text {-SEF alterations } \\
(22.22 \%) \\
\text {-Endocarditis } \\
(3.70 \%)\end{array}$ & $\begin{array}{l}\text {-Anemia }(44.44 \%) \\
\text {-Polyglobulia } \\
(18.52 \%)\end{array}$ & $\begin{array}{l}12 \text { deaths } \\
(44.44 \%)\end{array}$ \\
\hline SV & 0.64 & $61.54 \%$ & 39 months & -Cardiomegaly (78.57\%) & $\begin{array}{l}\text { RAH, LAH and } \\
\text { RVH (25\%) }\end{array}$ & -PAH (22.22\%) & $\begin{array}{l}\text {-Anemia } \\
(50 \%) \\
\text {-Polyglobulia }(50 \%)\end{array}$ & $\begin{array}{l}5 \text { deaths } \\
(27.77 \%)\end{array}$ \\
\hline PAOS & 1 & $60 \%$ & 23 months & $\begin{array}{l}\text {-Cardiomegaly }(83.33 \%) \\
\text {-Hypovascularization } \\
(25 \%)\end{array}$ & RVH (80\%) & & $\begin{array}{l}\text {-Anemia }(31.25 \%) \\
\text {-Polyglobulia } \\
(68.75 \%)\end{array}$ & $\begin{array}{l}4 \text { deaths } \\
(25 \%)\end{array}$ \\
\hline $\begin{array}{l}\text { CCC } \\
\text { COMPLEX } \\
\text { ES }\end{array}$ & 1.33 & $50 \%$ & 4 months & $\begin{array}{l}\text {-Cardiomegaly }(85.71 \%) \\
\text {-Hypovascularization } \\
(42.86 \%)\end{array}$ & RVH (100\%) & - SEF alteration & $\begin{array}{l}\text {-Anemia (14.29\%) } \\
\text {-Polyglobulia (50\%) }\end{array}$ & $\begin{array}{l}8 \text { deaths } \\
(57.14 \%)\end{array}$ \\
\hline
\end{tabular}

$\mathrm{CCHD}=$ congenital cyanogenic heart disease, $\mathrm{ECG}=$ electrocardiogram, $\mathrm{CAT}=$ common arterial trunk, $\mathrm{SV}=$ single ventricle, $\mathrm{PAOS}=$ pulmonary atresia with open septum, RVH = right ventricular hypertrophy, $\mathrm{LVH}=$ left ventricular hypertrophy, RAH = right atrial hypertrophy, PAH = pulmonary arterial hypertension, $\mathrm{SEF}=$ systolic ejection fraction.

\section{Discussion}

The hospital prevalence of CCHD seems to increase over the years with $0.87 \%$ in our study against $0.18 \%$ in 2011 [3]. This could be explained by the raising of the technical platform, the availability of cardiac ultrasound and the development of pediatric cardiology. The tetralogy of Fallot (T4F) remains the most frequent CCHD in our series as observed in several other studies [7] [8] [9]. The other types of CCHD most commonly found were the transposition of large vessels 
(TLV), the Double Issue Right Ventricle (DIRV) and Tricuspid atresia (TA). However, some severe CCHD are often lethal in the fetal or neonatal period and are underdiagnosed. The male prevalence observed in CCHD has been described in several other studies, but a direct correlation between sex and the occurrence of CCHD has not been established [8] [10]. There was a high percentage of parental consanguinity $(92.12 \%)$. Studies have shown that there is a correlation between parental consanguinity and the genesis of heart defects [11] [12]. The main genetic anomaly was trisomy 21 as described in the literature [13]. The average age at diagnosis was 16 months. This delay in diagnosis is explained by the fact that in our developing countries, the discovery is often made after decompensation due to a lack of diagnostic means and limited access to patient care linked to the low socioeconomic level [10]. The age at diagnosis is later in T4F (25 months), the single ventricle (39 months) and tricuspid open septum atresia (23 months) because of the later onset of cyanosis. Unlike other types of CCHD where it appears earlier. This situation contrasts with that of developed countries where the diagnosis is often made in antenatal [14]. The main reasons for consultation were respiratory signs and the main associated pathology was bronchiolitis. Respiratory infections are frequent revealing circumstances [15]. In biology we note a predominance of polyglobulia which is the consequence of hypoxia [16] [17]. This hypoxia was also at the origin of the frequent anoxic crisis in T4F. The number of patients who have undergone surgical treatment remains very low compared to Western countries [17]. This would be linked on the one hand to the high cost of cardiac surgery and on the other hand to an insufficiency of the surgical technical platform. The medical treatment consisted mainly in the prevention of anoxic crises and in the management of associated pathologies. Surgical repair is indicated in all cases for T4F. The medical and surgical management of TLV and DIRV remains difficult due to their brutal and early revelations [17]. Despite all the actions taken to improve care, there is a considerable gap between the number of children in need of surgical treatment and those who benefit from it. This explains the high mortality in our country. This mortality seems lower in T4F compared to other types of CCHD.

\section{Limits of the Study}

The limits of this study are linked to the retrospective nature of our study. These include the presence of several incomplete files, the unavailability of caryotyping.

\section{Conclusion}

The diagnosis of CCHD is late in our country and surgical management is poor explaining a high mortality. This is linked to a difficulty in accessing diagnostic means and the limits of the technical platform. Improving the prognosis of CCHD requires the establishment of antenatal diagnosis, extensive neonatal screening for cardiac anomalies; the raising of technical platforms in the pediatric and maternity departments as well as the strengthening of resources in the 
cardiovascular surgery department.

\section{Conflicts of Interest}

The authors declare no conflicts of interest regarding the publication of this paper.

\section{References}

[1] Iselin, M. Cyanogenic Heart Disease. http://www.em-consulte.com/article/22837/cardiopathies-cyanogenes

[2] Iselin, M. (1999) Cardiopathies congénitales. Radiodiagnostic-Cour-Poumon, 32-015-A-12, Pédiatrie, 4-070-A-05, EMC, Paris (Elsevier), 6 p.

[3] Planche, C., Lacour-Gayet, F., Serraf and Bruneaux, J. (1993) Traitement chirurgical de Transposition complète des gros vaisseaux Editions techniques. Techniques chirurgicales-Thorax, 42-817, EMC, Paris, 22 p.

[4] Delpart, A., Jimenez, M. and Choussat, A. (2002) Intérêt de L'échographie cardiaque fotale dans le dépistage des cardiopathies congénitales. Arch Mal Coeur, 95, 461-468.

[5] Bonnet, D. (2006) Epidémiologie et génétique des cardiopathies congénitales et des cardiomyopathies de l'enfant. La Revue du Praticien, 56, 599-604.

[6] Hammerli, M. (2005) Screening of Congenital Heart Diseases. Paediatrica, 16, 24-25.

[7] Abdirahman, N.A. (2011) Epidemiological Aspects of Congenital Heart Disease in Pediatrics about 249 Cases. Thesis Med. UCAD, No. 204.

[8] Bah, K.A. (2007) Congenital Heart Disease in Pediatric Settings. Thesis Med. UCAD, Numbers 132 .

[9] Diop, A. (2007) Congenital Heart Disease in Dakar: About 72 Cases Collected in the Pediatrics Department of the Main Hospital of Dakar. Thesis Med., Cheikh Anta Diop University of Dakar, No. 89.

[10] Diop, I.B., Ba, S.A., Ba, K., Sarr, M., Kane, A., Fall, M., et al. (1995) Congenital Heart Disease: Anatomo-Clinical, Prognostic and Therapeutic Aspects in Relation to 103 Cases Observed at the Cardiology Clinic of the Dakar CHU. Dakar-Médical, 40, 181-186.

[11] Becker, S.M., Zohair Al, H.C. and Molina, C. (2001) Consanguinity and Congenital Heart Disease in Saudi Arabia. American Journal of Medical Genetics, 99, 8-13. https://doi.org/10.1002/1096-8628(20010215)99:1<8::AID-AJMG1116>3.0.CO;2-U

[12] Mouzan, I., Al Salloum, A.A., Al Herbish, A.S., et al. (2008) Consanguinity and Major Genetic Disorders in Saudi Children: A Community-Based Cross-Sectional Study. Annals of Saudi Medicine, 28, 169-173. https://doi.org/10.5144/0256-4947.2008.169

[13] Harris, J.A., Francannet, C. and Pradat, P. (2003) The Epidemiology of Cardiovascular Defects, Part 2: A Study Based on Data from the Large Registries of Congenital Malfonnations. Pediatric Cardiology, 24, 222-235. https://doi.org/10.1007/s00246-002-9402-5

[14] From GEETERB (2004) Antenatal Diagnosis of Transposition of Large Vessels. Arch Mal Coeur, 97, 580-581.

[15] Abena, O.M.T., Muna, W.F.T., Leckpa, J.P., et al. (1995) Cardiovascular Disorders in Sub-Saharan African Children: A Hospital-Based Experience in Cameroon. 
Tropical Cardiology, 21, 5-11.

[16] Building, A. (2002) Practical Pediatric Cardiology. 2nd Edition, Doins Editeurs, Paris.

[17] Boussalah, M., Ahmed, A.A., Salimi, S., et al. (2010) Epidemiology and Prognosis of Congenital Heart Diseases in Pediatrics. Archives de Pédiatrie, 17, 150. https://doi.org/10.1016/S0929-693X(10)70794-6 